\title{
Sistem Informasi Pelayanan Jasa Laundry Sepatu Pada Queen Shoes Cleaning
}

\author{
Syifa Nur Rakhmah ${ }^{1,{ }^{*}}$, Irfan Rizki ${ }^{1}$ \\ ${ }^{1}$ Fakultas Teknologi Informasi; Universitas Nusa Mandiri; Jln. Jatiwaringin Raya No 01 RT 08/ \\ RW 013 Kelurahan cipinang melayu kecamatan makassar Jakarta Timur, 0218005722; e-mail: \\ syifa.snk@nusamandiri.ac.id, irfanrizki2017@gmail.com
}

* Korespondensi: e-mail: syifa.snk@nusamandiri.ac.id

Submitted: 05/01/2022; Revised: 13/01/2022; Accepted: 24/01/2022; Published: 31/01/2022

\begin{abstract}
Shoes are one of the complementary tools to support one's appearance, over time shoes become a very important aspect to pay attention to, the development of the times makes the shoe industry compete in innovation in terms of design or color. With the technology that has developed at this time, it can be used in all aspects of the industry, one of which is in the business or business sector at the Queen Shoes Cleaning store. The process used at this time is still carried out by recording services, making reports, and also storing transaction evidence manually so that the documents are messy. In the future, there is a very big risk of losing the documents in the store. For this reason, the author makes the idea of building a website-based information system in which you can order services, print reports, make receipts, and see shoe washing prices. There are 3 users in this system, namely regular visitors, registered visitors, and admins. For ordinary employees can only see the price list, about the store, the type of service. Then members can make transactions, print transaction receipts, and admins can process incoming transactions, print incoming reports, view user data, and view admin data. The method used in conducting this research is descriptive method, combining data collection methods and system development methods. With this website-based shoe washing service information system, it can help and simplify the shoe washing service process
\end{abstract}

Keywords: Cleaning Shoes, Descriptive Method, Website

\begin{abstract}
Abstrak
Sepatu merupakan salah satu alat pelengkap untuk menunjang penampilan seseorang, seiring berjalannya waktu sepatu menjadi aspek yang sangat penting untuk di perhatikan, berkembangnya zaman membuat industry sepatu belomba-lomba dalam inovasi dari segi design ataupun warna. Dengan adanya teknologi yang sudah berkembang saat ini dapat digunakan pada segala aspek industry, salah satunya di bidang usaha atau bisnis pada toko Queen Shoes Cleaning. Proses yang digunakan pada saat ini masih dilakukan dengan mencatat pelayanan, membuat laporan, dan juga penyimpanan bukti transaksi secara manual sehingga membuat dokumen berantakan. Kedepannya memiliki resiko sangat besar kehilangan dokumen yang ada pada toko tersebut. Untuk itu penulis membuat gagasan untuk membangun sebuah sistem informasi berbasis website yang didalamnya bisa melakukan pemesanan pelayanan, mencetak laporan, membuat kwitansi, dan melihat harga pencucian sepatu. Terdapat 3 user pada sistem ini yaitu pengunjung biasa, pengunjung terdaftar, dan juga admin. Untuk karyawan biasa hanya dapat melihat daftar harga, tentang toko, jenis pelayanan. Kemudian untuk member dapat melakukan transaksi, mencetak bukti transaksi, dan untuk admin dapat memproses transaksi yang masuk, mencetak laporan yang masuk, melihat data pengguna, melihat data admin. Metode yang digunakan dalam melakukan penelitian kali ini adalah menggunakan metode deskriptif, dengan menggabungkan metode pengumpulan data dan metode pengembangan sistem Dengan adanya sistem informasi pelayanan cuci sepatu
\end{abstract}


berbasis website ini dapat membantu dan mempermudahkan proses pelayanan pencucian sepatu.

Kata kunci: Cuci Sepatu, Metode Deskriptif, Website

\section{Pendahuluan}

Perkembangan teknologi informasi pada masa sekarang sangat berperan penting untuk membantu permasalahan dalam proses suatu kegiatan, salah satunya di bidang usaha atau bisnis. Sistem informasi pelayanan merupakan suatu program aplikasi computer yang digunakan untuk mendukung penyimpanan data dan informasi, melaporkan masukan data dan informasi, menampilkan data dan informasi, serta memberikan informasi kepada semua orang yang membutuhkan. Keadaan tersebut yang membuat banyak perusahaan memanfaatkan sistem yang terkomputerisasi, untuk meningkatkan pengembangan di bidang pelayanan jasas sehingga bisa menjadi lebih baik, salah satunya di bidang pelayanan jasa cuci sepatu (Yulisar, 2019).

Sepatu merupakan salah satu alat pelengkap untuk menunjang penampilan seseorang, seiring berjalannya waktu sepatu menjadi aspek yang sangat penting untuk di perhatikan, berkembangnya zaman membuat industry sepatu belomba-lomba dalam inovasi dari segi design ataupun warna. Konsumen sangat mementingkan kebersihan sepatu terutama sepatu yang mempunyai warna dominan putih. Sepatu dengan warna-warna cerah sangat rentan kotor maka dari itu perlu sebuah informasi tentang seberapa tingkat kekotoran sepatu, selain perlu informasi mengukur tingkat kekotoran sepatu maka dibutuhkan cara untuk membersihkan sepatu agar sesuai dengan tingkat kekotoran sepatu dan keinginan pelanggan, maka dibutuhkan suatu system yang dapat mendeteksi tingkat kekotoran sepatu serta treatment untuk membersihkan sepatu sesuai tingkat kekotorannya dan keinginan customer. Tidak sedikit pula masyarakat membeli sepatu dengan kisaran harga hingga jutaan rupiah. Hal ini menandakan sepatu bukan hanya sekedar alat untuk melindungi kaki namun sebagai penunjang gaya hidup dan benda yang sangat penting. Dengan sepatu yang mahal pengguna tidak akan sembarangan memakai dan merawat sepatunya. Banyak masyarakat umum mengangap cara mencuci sepatu itu sama halnya seperti mencuci pakaian. Sedangkan, merawat sepatu bukan hanya dicuci dengan air lalu disikat dengan sabun dikarenakan sepatu terbuat dari berbagai jenis bahan yang berbeda dengan perawatan yang berbeda pula tentunya (Hudaya \& Suryana, 2018).

Dikarenakan sedikitnya pengetahuan masyarakat mengenai cara mencuci sepatu dengan benar ini akan menjadi peluang bisnis yang bagus dengan membuka usaha jasa laundry sepatu. Tetapi sebagian besar bisnis usaha laundry ini masih menggunakan sistem yang manual seperti cara pemesanan yang hanya dapat dilakukan dengan cara menghubungi lewat aplikasi whatsapp, bukti transaksi yang masih menggunakan kertas manual, dan masih harus datang ke toko untuk memberikan sepatu yang ingin kita cuci. Tujuan dari adanya penelitian ini adalah untuk membuat sebuah aplikasi yang dapat mempermudah kita untuk 
melakukan pencucian sepatu tanpa harus kita datang ke toko laundry sepatu (Raksipratama \& lqbal Firdaus, 2020).

Berdasarkan informasi yang didapatkan oleh penulis dengan cara observasi langsung ke Queen Shoes Cleaning Pondok Ungu Permai, tentang bagaimana proses cara pencucian dan cara pemesanan pada toko tersebut, sedangkan untuk persentase pencucian yang di lakukan oleh toko tersebut yakni 20 pcs perbulan.

Adapun faktor penyebab minimnya persentase tersebut yaitu tidak ada pemasaran yang menarik, tidak adanya sistem antar dan jemput untuk pelanggan, tidak dapat menarik perhatian pelanggan karena untuk pemesanannya hanya dapat dilakukan via whatsapp dan datang langsung ke toko tersebut. Sedangkan pelanggan menginginkan cara yang praktis dan dapat dilakukan dengan mudah dalam artian tidak perlu repot datang ke toko untuk mencuci sepatu.

Selama ini proses pengelolaan data dan pencatatan transaksi dilakukan dengan pencatatan manual, sehingga untuk melakukan pencarian data masih dianggap merepotkan dan membutuhkan waktu yang lama. Selama ini sering terjadi kesalahan dalam pengolahan data pencucian sepatu yang tidak terkontrol dan pembuatan laporan masih relatif lama. Melihat latar belakang tersebut, maka dianggap perlu untuk membuat sistem informasi pelayanan jasa cuci sepatu berbasis web agar pencatatan transaksi dan pengelolaan data bias berjalan lebih cepat dan mengurangi terjadinya human error yang akan merugikan berbagai pihak. Dengan menggunakan sistem aplikasi website diharapkan dapat mempermudah pekerjaan karyawan maupun pemilik toko.

Berdasarkan permasalahan yang ada, maka tujuan dari pembuatan sistem ini antara lain: Mengetahui proses bisnis dan permasalahan bisnis jasa laundry sepatu. Merancang dan menerapakan sistem baru yang terkomputerisasi sebagai solusi terhadap permasalahan yang ada. Merancang sebuah sistem informasi yang dapat menyajikan data secara cepat, tepat dan akurat untuk landasan pengambilan keputusan oleh pemilik bisnis laundry sepatu. Memberikan kemudahan bagi pelanggan yang ingin mencuci sepatu tanpa harus datang langsung ke toko.

\section{Metode Penelitian}

Metode penelitian merupakan tahap-tahap penyelesaian penelitian dari awal hingga akhir berdasarkan kaidah penelitian yang digunakan untuk memperoleh data-data yang relevan. Dalam hal ini penulis melakukan beberapa tahapan dengan cara sebagai berikut:

\subsection{Metode Pengumpulan Data}

Pada proses pengumpulan data, penulis melakukan beberapa tahapan-tahapan diantaranya yaitu observasi, wawancara dan studi Pustaka.

Metode observasi yaitu teknik pengumpulan data dengan mengadakan pengamatan langsung terhadap objek yang diteliti serta mencatat kejadian yang berkaitan dengan penelitian yang dilakukan penulis. Dalam hal ini, penulis mendatangi dan melihat langsung sistem berjalan pada salah satu usaha laundry sepatu Queen Shoes Cleaning yang beralamat Gang Karisma 
Jalan Lapangan No 80 RT002/016, Kaliabang Tengah, Bekasi Utara, Kota Bekasi Jawa Barat 17125. Mulai dari transaksi penerimaan laundry sepatu sampai proses penyajian data transaksi (laporan) yang digunakan sebagai bahan pertimbangan dalam mengambil keputusan pemilik usaha laundry sepatu dan penulis mengamati website www.cucisepatu.id sebagai acuan dan referensi.

Metode wawancara yaitu perolehan data dengan cara mengadakan percakapan langsung dan tanya jawab yang ada hubungannya dengan objek yang sedang di teliti oleh penulis. Dalam hal ini, proses wawancara dilakukan penulis kepada saudara fandi ramadhan selaku pemilik usaha Queen Shoes Cleaning dan saudara jody selaku karyawan Queen Shoes Cleaning.

Dalam metode ini, pengumpulan data dilakukan dengan cara mempelajari buku-buku yang mendukung, termasuk didalamnya literature tentang penulisan dan mengenai hal-hal yang mendukung pembuatan program aplikasi. Juga mempelajari dari sumber data yang lain seperti dari internet dan CD referensi program (Sofian, 2017).

\subsection{Model Pengembangan Sistem}

Model SDLC air terjun (waterfall) sering juga disebut model sekuensial linier (sequential liniear) atau alu hidup klasik (classic lifecycle). Model air terjun menyediakan pendekatan alur hidup perangkat lunak secara sekuensial atau terurut dimulai dari anailisis, desain, pengodean, pengujian dan tahap pendukung (support). Berikut ini tahapan-tahapan yang ada pada SDLC secara global, yaitu analisa kebutuhan software, desain, code generation, testing dan support (Pressmann, 2015).

Tahap analisa kebutuhan software, dalam proses pengembangan sebuah software langkah awal yang perlu dilakukan yaitu menganalisa berbagai kebutuhan yang akan dijadikan sebagai masukan atau acuan dalam pembangunan software tersebut. Kebutuhan-kebutuhan tersebut antara lain seperti input yang diperlukan, output yang diharapkan dan pembuatan design user interface yang mudah digunakan dan mudah dipahami oleh user.

Tahap desain yang dilakukan mendesain sebuah aplikasi ini penulis mendasain sesuai kebutuhan sistem yang akan dibuat terkait rancangan database yang digunakan untuk membuat Entity Relationship Diagram, Logical Record Structure, spesifikasi file, Class Diagram, Sequence Diagram, dan user interface yang akan dibuat. Penggunaan Unified Modeling Langueage (UML) dimkasud menjelaskan lebih terperinci dalam rancangan pembuatan program dan rancangan database. UML yang akan digunakan adalah Activity Diagram (Soekamto \& Shalahuddin, 2018).

Tahap code generation merupakan tahapan tarnformasi ke dalam bahasa pemrograman. Bahasa pemograman yang akan digunakan oleh penulis yaitu PHP, JavaScript, CSS, HTML, dan menggunakan php Myadmin sebagai database (Nugroho, 2013).

Tahap testing atau pengujian dilakukan menggunakan teknik Black Box Testing dengan menghasilkan sesuai dengan harapan yang telah dirancang sebelumnya (Khasanah et al., 
2018). Penggunaan black box dalam pengujian aplikasi akan memberikan penjelasan tentang kesesuaian harapan dalam pembuatan program.

Tahap support merupakan proses pemeliharaan ini penulis mengupayakan pengembangan sistem yang sudah dibuatkan terkait software dan hardware yang akan digunakan, dan untuk penghostingannya penulis melakukan pada website yang dapat kita jumpai di www.niagahoster.co.id.

\section{Hasil dan Pembahasan}

Pembahasan masalah yang ada dari perancangan program ini, adapun batasan permasalahan dalam penilitian ini yaitu pada Front end dan back end. Untuk front end pada pengguna website biasa hanya dapat mengakses tampilan beranda, tampilan tentang pelayanan yang disediakan, tampilan pelayanan yang disediakan, gallery, daftar harga, kontak, tampilan login, dan cara pendaftaran menjadi anggota. Sedangkan untuk front end pengguna yang telah terdaftar di website dapat mengakses seperti dashboard, membuat transaksi, melihat riwayat transaksi, mengganti password, untuk front end hanya dapat melihat tampilan login sedangkan untuk back end pada admin dapat melihat dashboard, dapat menambahkan tipe pelayanan, menambahkan jenis pelayanan, dapat melihat berapa banyak member yang terdaftar,dapat melihat orderan yang masuk dan mencetaknya, dapat melihat pesan yang di sampaikan oleh pelanggan,dan merubah password (Widodo \& Kurnianingtyas, 2017).

\subsection{Tahap Analisis}

Pengertian E-Commerce adalah suatu proses yang dilakukan konsumen dalam membeli dan menjual berbagai produk secara elektronik dari perusahaan ke perusahaan lain dengan manggunakan komputer sebagai perantara transaksi bisnis yang dilakukan atau melakukan transaksi jual beli melalui internet (Khasanah et al., 2019) (Merdeka, 2021). Berikut ini spesifikasi kebutuhan dari sistem e-commerce:

Halaman Front-page:

A1. User biasa hanya dapat melihat beranda.

A2. User biasa hanya dapat melihat informasi tentang pelayanan.

A3. User biasa hanya dapat melihat pelayanan yang diberikan.

A4. User biasa hanya dapat melihat koleksi galeri.

A5. User iasa hanya dapat melihat daftar harga.

A6. User biasa hanya dapat melihat kontak.

A7. User biasa dapat melakukan login.

A8. User biasa dapat melakukan registrasi.

Halaman User:

B1. User dapat melihat dashboard.

B2. User dapat memilih pelayanan.

B3. User dapat melakukan transaksi.

B4. User dapat melihat detail pemesanan. 
B5. User dapat mencetak kwitansi.

B6. User dapat mengubah password.

B7. User dapat melihat cara pemesanan.

B8. User dapat mengupload bukti pembayaran.

Halaman Admin:

C1. Admin dapat melihat dashboard

C2. Admin dapat mengubah status pesanan pelanggan

C3. Admin dapat menambahkan tipe pelayanan

C4. Admin dapat menambahkan jenis pelayanan

C5. Admin dapat melihat user yang terdaftar

C6. Admin dapat mengelola pesanan

C7. Admin dapat mencetak laporan pemasukan

C8. Admin dapat melihat pesan kritik dan saran yang di berikan pelanggan

C9. Admin dapat mengubah password

\subsection{Use Case Diagram}

Dalam sebuah usecase terdiri dari berbagai kemungkinan interaksi antara sistem dengan penguna yang mendefinisikan fitur yang ingin diimplementasikan dan resolusi dari semua kesalahan yang akan dihadapi. Berikut adalah gambar usecase diagram yang terdiri dari dua aktor yaitu user (pengguna) dan admin (M.Shalahuddin, 2016).

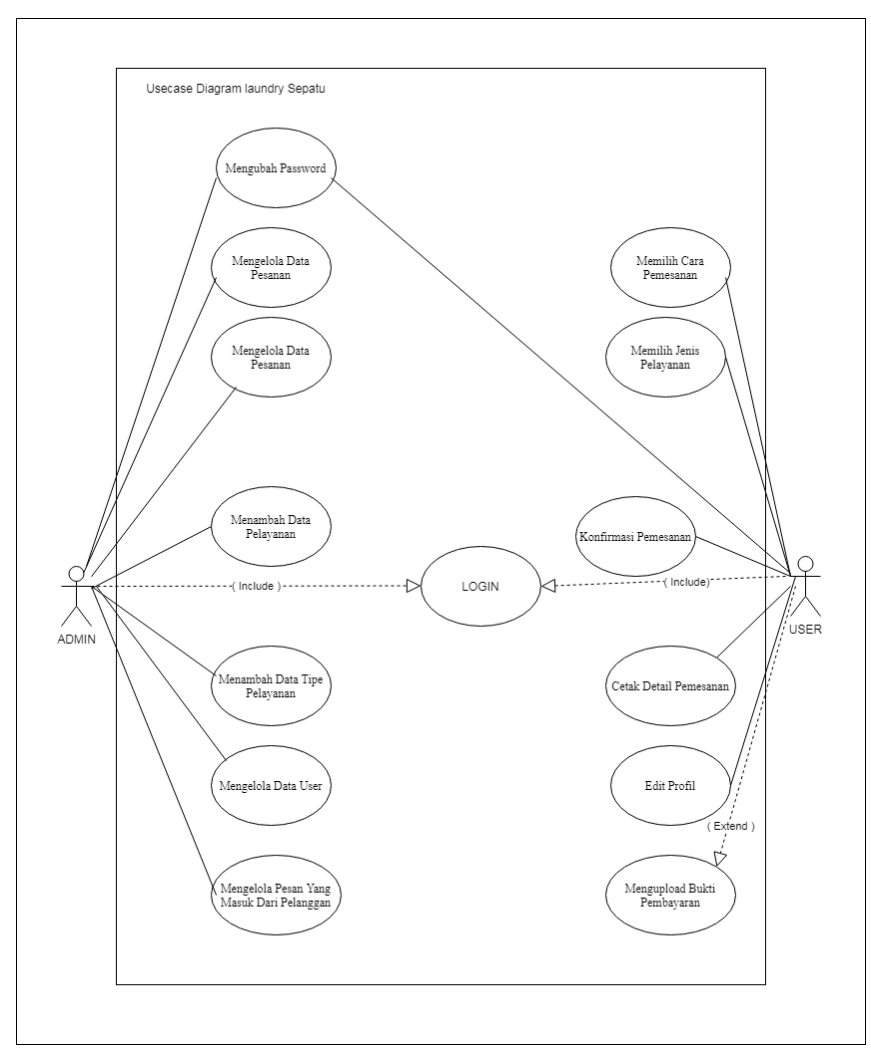

Sumber: Hasil Penelitian (2021)

Gambar 1. Usecase Diagram Laundry Sepatu 
Berikut deskripsi usecase berdasarkan gambar usecase diagram yang ditunjukkan pada gambar 1. Tabel 1 menunjukkan deskripsi usecase pada tahap mengubah password.

Tabel 1. Deskripsi Usecase Mengubah Password

\begin{tabular}{ll}
\hline Use case name & Mengubah password admin \\
\hline Requirements & C9 \\
\hline Goal & Admin dapat mengubah password \\
\hline Pre-conditions & Admin telah login \\
\hline Post-conditions & Tampil data ubah password, password berhasil diubah \\
\hline Failed end condition & Gagal merubah password admin \\
\hline Primary Actors & Admin \\
\hline Main Flow/ Basic Path & 1. admin memilih change password \\
\hline & 2. sistem akan menampilkan form ubah password \\
\hline & 3. admin memasukkan password baru \\
\hline & 4. admin memilih button change password \\
\hline Invariant & 5. sistem menyimpan data perubahan password admin \\
\hline
\end{tabular}

Sumber: Hasil Penelitian (2021)

Tabel 2 menunjukkan deskripsi pada usecase mengelola data pesanan

Tabel 2. Deskripsi Usecase Mengelola Data Pesanan

\begin{tabular}{ll}
\hline Use case name & Mengelola data pesanan \\
\hline Requirements & C6 \\
\hline Goal & Admin dapat mengelola pesanan masuk \\
\hline Pre-conditions & Admin telah login \\
\hline Post-conditions & Tampil data pesanan, data pesanan dapat diupdate \\
\hline Failed end conditions & Gagal mengupdate pesanan \\
\hline Primary actors & Admin \\
\hline Main flow/ basic path & 1. admin login terlebih dahulu \\
\hline & 2. sistem akan mengarahkan ke button dashboard \\
\hline & $\begin{array}{l}\text { 3. admin dapat melihat pesanan dengan menekan button } \\
\text { view }\end{array}$ \\
\hline & 4. sistem akan menampilkan pesanan yang ada \\
\hline & 5. admin dapat mengupdate pesanan dengan menekan \\
button change status
\end{tabular}

Tabel 3 menunjukkan deskripsi pada usecase pada tahap menambahkan data pesanan.

Tabel 3. Deskripsi Usecase menambahkan Data Pesanan

\begin{tabular}{ll}
\hline Use case name & Mengelola data pesanan \\
\hline Requirements & C1 \\
\hline Goal & Admin dapat mengelola pesanan masuk \\
\hline Pre-conditions & Admin telah login \\
\hline Post-conditions & Tampil data pesanan, data pesanan dapat diupdate \\
\hline Failed end condition & Gagal mengupdate pesanan \\
\hline Primary Actors & Admin \\
\hline Main Flow/ Basic Path & 1. admin login terlebih dahulu \\
\hline & 2. sistem akan mengarahkan ke button dashboard \\
\hline & $\begin{array}{l}\text { 3. admin dapat melihat pesanan dengan menekan button } \\
\text { view }\end{array}$ \\
\hline & 4. sistem akan menampilkan pesanan yang ada \\
\hline & $\begin{array}{l}\text { 5. admin dapat mengupdate pesanan dengan menekan } \\
\text { button change status }\end{array}$ \\
\hline & 6. sistem akan menampilkan pilihan untuk diubah \\
\hline
\end{tabular}




\begin{tabular}{ll}
\hline Use case name & Mengelola data pesanan \\
\hline & pesanan yang dipilih \\
\hline Invariant & 7. admin memilih pilihan perubahan pesanan \\
\hline Sumber: Hasil Penelitian (2021) & - \\
\hline
\end{tabular}

Tabel 4 menunjukkan deskripsi pada usecase pada tahap menambahkan data jenis pelayanan.

Tabel 4. Deskripsi Usecase menambahkan Data Jenis Pelayanan

\begin{tabular}{ll}
\hline Use case name & Mengelola data jenis pelayanan \\
\hline Requirements & C4 \\
\hline Goal & Admin dapat menambahkan data pelayanan \\
\hline Pre-conditions & Admin telah login \\
\hline Fast-conditions & Tampil data pelayanan, data pelayanan dapat dihapus \\
\hline Primary Actors & Gagal menambahkan dan menghapus data pelayanan \\
\hline Main Flow/ Basic Path & Admin \\
\hline & 1. admin login terlebih dahulu \\
\hline & 2. admin memilih button services add \\
\hline & 3. sistem akan menampilkan tampilan services add \\
\hline & 4. admin dapat memilih pelayanan \\
\hline & $\begin{array}{l}\text { di admin harus memasukkan nama pelayanan yang ingin } \\
\text { diambahkan }\end{array}$ \\
\hline $\begin{array}{l}\text { 6. admin harus memasukkan biaya cuci yang ingin } \\
\text { ditambahkan }\end{array}$ \\
\hline 7. admin memilih pilihan button submit \\
\hline $\begin{array}{l}\text { 8. sistem akan menampilkan pesan pelayanan berhasil } \\
\text { ditambahkan }\end{array}$ \\
\hline 9. admin memilih button delete \\
\hline $\begin{array}{l}\text { 10. sistem akan menampilkan pesan apakah kamu yakin } \\
\text { ingin menghapusnya }\end{array}$ \\
\hline 11. admin memilih button oke \\
\hline Invariant & - \\
\hline Sumber: Hasil Penelitian (2021) &
\end{tabular}

Tabel 5 menunjukkan deskripsi pada usecase pada tahap konfirmasi pesanan pada aplikasi.

Tabel 5. Deskripsi Usecase Konfirmasi Pesanan

\begin{tabular}{ll}
\hline Use case name & Konfirmasi Pemesanan User \\
\hline Requirements & B3 \\
\hline Goal & User dapat mengkonfirmasi pemesanan \\
\hline Pre-conditions & User telah login \\
\hline Post-conditions & $\begin{array}{l}\text { Tampil data konfirmasi pesanan, pesanan telah } \\
\text { dilakukan }\end{array}$ \\
\hline Failed end condition & Gagal menambahkan pesanan \\
\hline Primary Actors & User \\
\hline Main Flow/ Basic Path & 1. User Login terlebih dahulu \\
\hline & 2. user memilih menu konfirmasi pemesanan \\
\hline & $\begin{array}{l}\text { 3. sistem akan menampilkan tampilan konfirmasi } \\
\text { pemesanan }\end{array}$ \\
\hline & 4. User memasukan alamat \\
\hline & 5. User memilih button submit \\
\hline Invariant & 6. Sistem akan menampilkan pesan, pesanan anda telah \\
Sumber: Hasil Penelitian (2021) & berhasil ditambahkan \\
\hline
\end{tabular}

\subsection{Activity Diagram}

Pembahasan pada sub bab ini akan menampilkan beberapa hasil rancangan activity diagram pada beberapa menu aplikasi Cleaning Shoes, diantaranya pada menu halaman login 
user, halaman login admin, halaman admin menambahkan layanan, halaman user konfirmasi pesanan, halaman user upload bukti pembayaran dan halaman admin tambah pelayan.

Pada activity diagram halaman login user, user harus memasukan akun yang telah terdaftar terlebih dahulu sebelum melakukan trasaksi, jika user berhasil memasukan akun yang terlah terdaftar otomatis akan dialihkan ke halaman user, tetapi jika user gagal memasukan akun yang telah terdaftar maka akan tetap berada pada halaman login user.

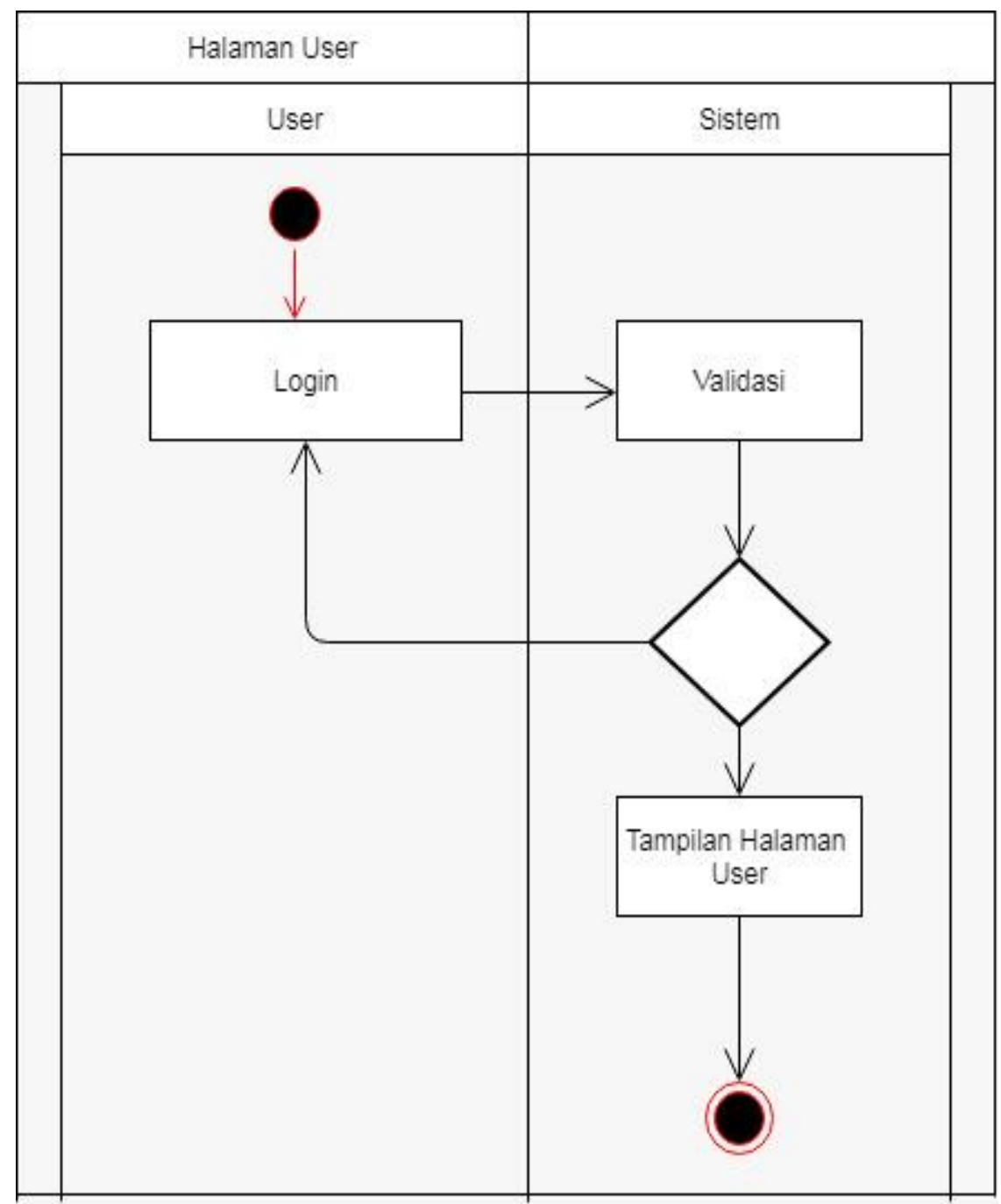

Sumber: Hasil Penelitian (2021)

Gambar 2. Activity Diagram Halaman Login User

Activity diagram halaman login admin. Admin harus memasukan akun yang telah terdaftar terlebih dahulu sebelum melakukan trasaksi, jika user berhasil memasukan akun yang terlah terdaftar otomatis akan dialihkan ke halaman admin, tetapi jika admin gagal memasukan akun yang telah terdaftar maka akan tetap berada pada halaman login user. 


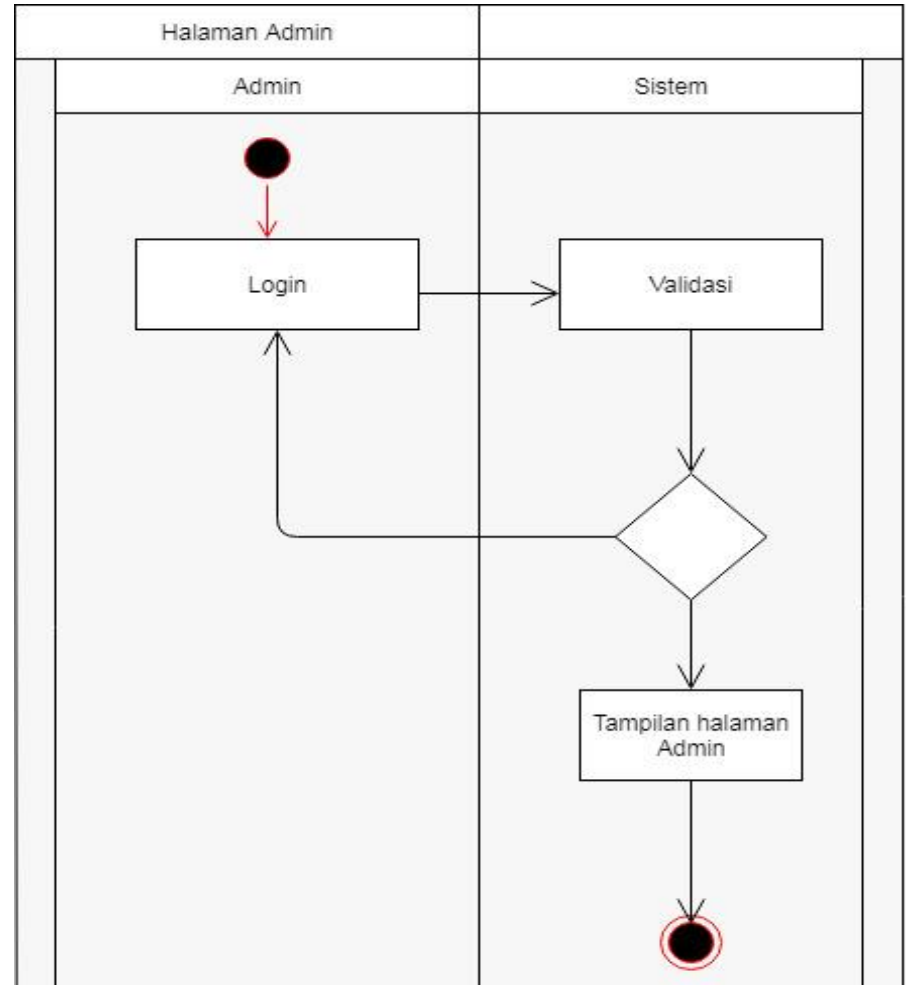

Sumber: Hasil Penelitian (2021)

Gambar 3. Activity Diagram Halaman Admin Login

Activity diagram halaman admin menambah pelayanan untuk menambah pelayanan pada website

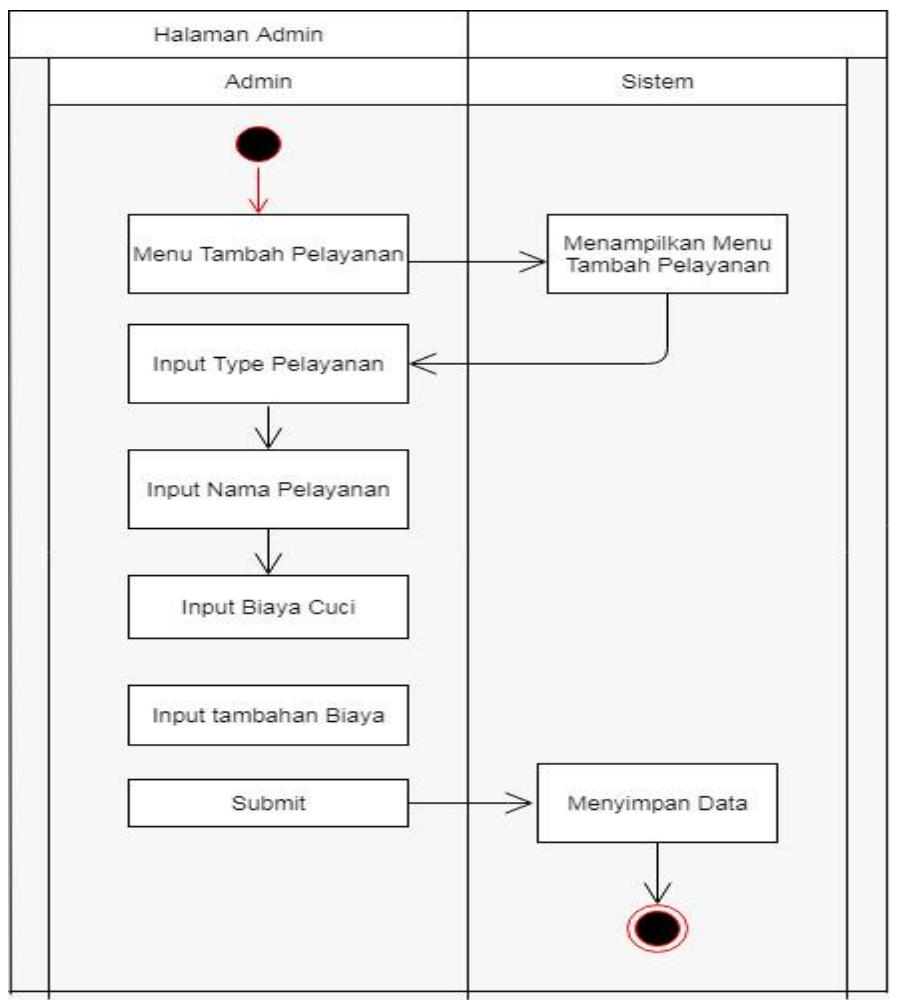

Sumber: Hasil Penelitian (2021)

Gambar 4. Activity Diagram halaman admin menambah pelayanan 
Activity diagram halaman user konfirmasi pesanan ditunjukkan pada gambar 5.

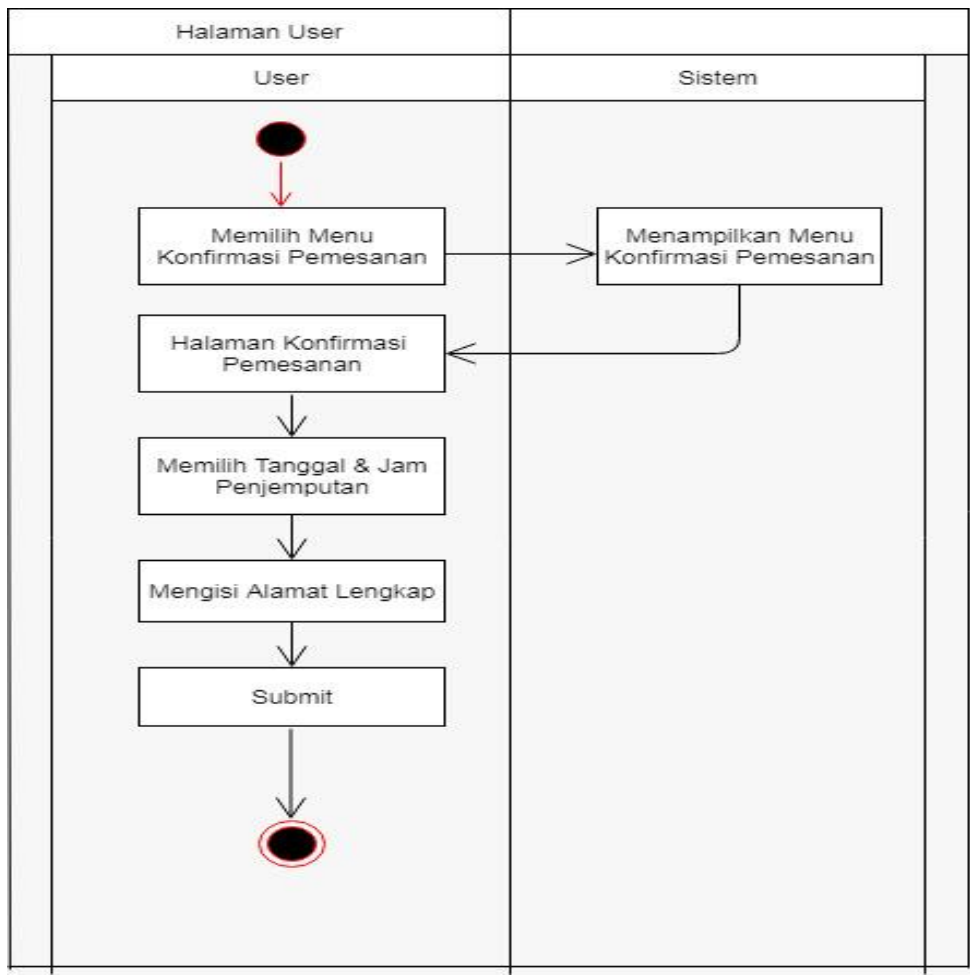

Sumber: Hasil Penelitian (2021)

Gambar 5. Activity diagram halaman user konfirmasi pesanan

Halaman user upload bukti pembayaran, berikut adalah activity diagram halaman user upload bukti pembayaran.

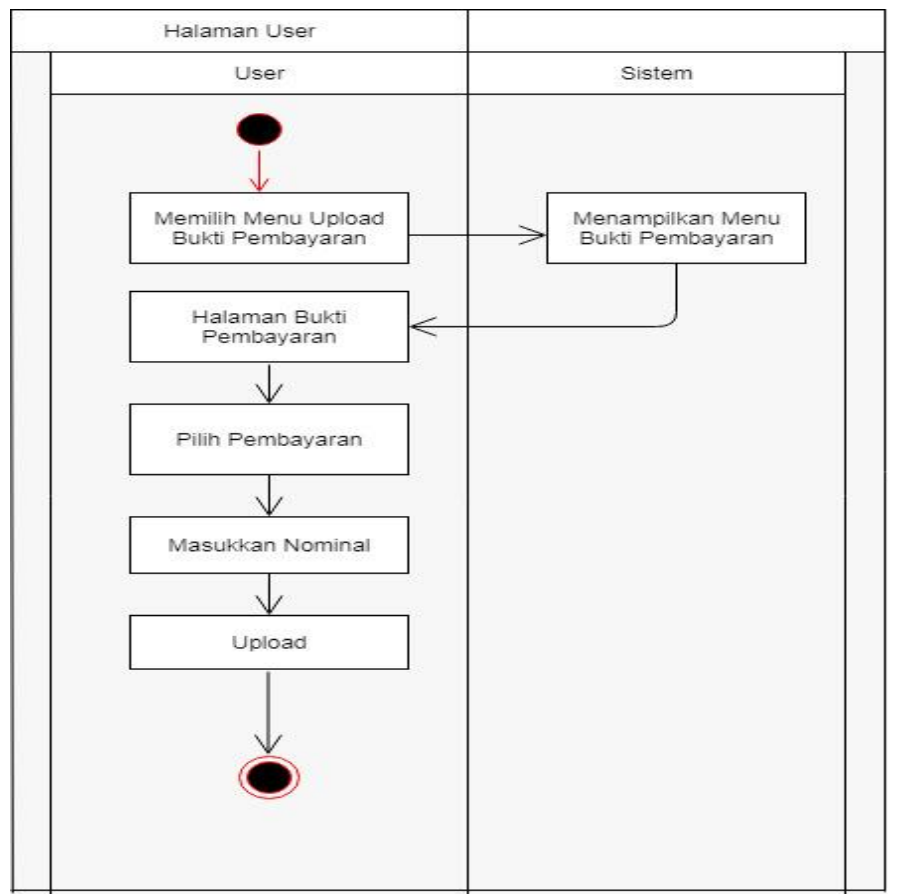

Sumber: Hasil Penelitian (2021)

Gambar 6. Activity diagram halaman user upload bukti pembayaran 
Halaman admin tambah pelayan, berikut activity halaman admin tambah pelayan.

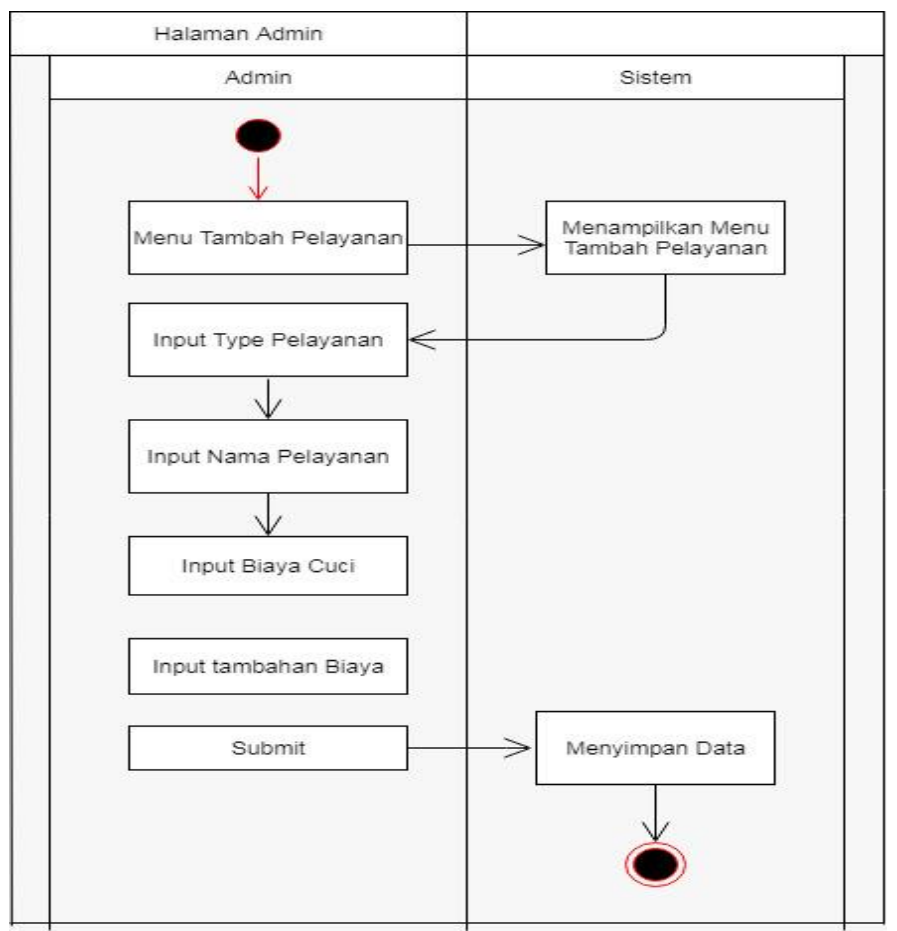

Sumber: Hasil Penelitian (2021)

Gambar 7. Activity Diagram halaman admin tambah pelayanan

\subsection{Sequence Diagram}

Sequence diagram adalah diagram interaksi yang merinci bagaimana sebuah operasi dilakukan. Sequence diagram atau diagram urutan menggambarkan interaksi antar kelas dalam hal pertukaran pesan dari waktu ke waktu. Berikut adalah gambar sequence diagram pada aplikasi laundry.

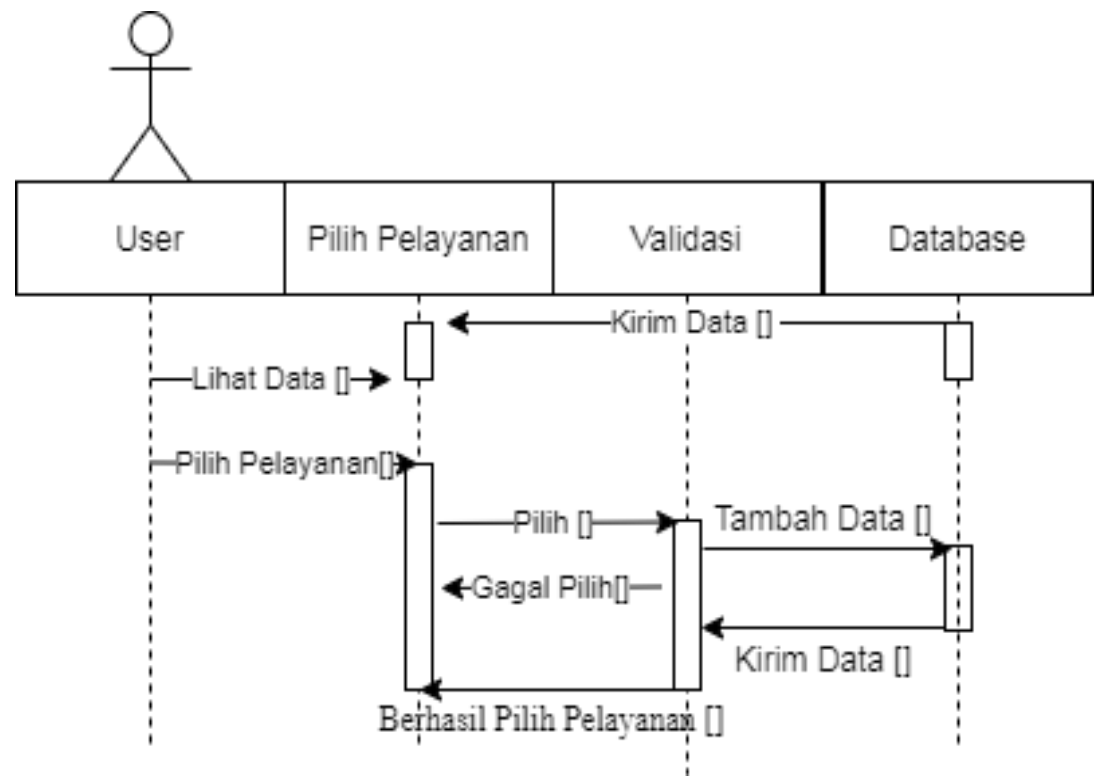

Sumber: Hasil Penelitian (2021)

Gambar 8. Diagram Sequence Halaman Pilih Pelayanan 
Pada gambar 9 menunjukkan sequence diagram pada tahap konfirmasi pesanan.

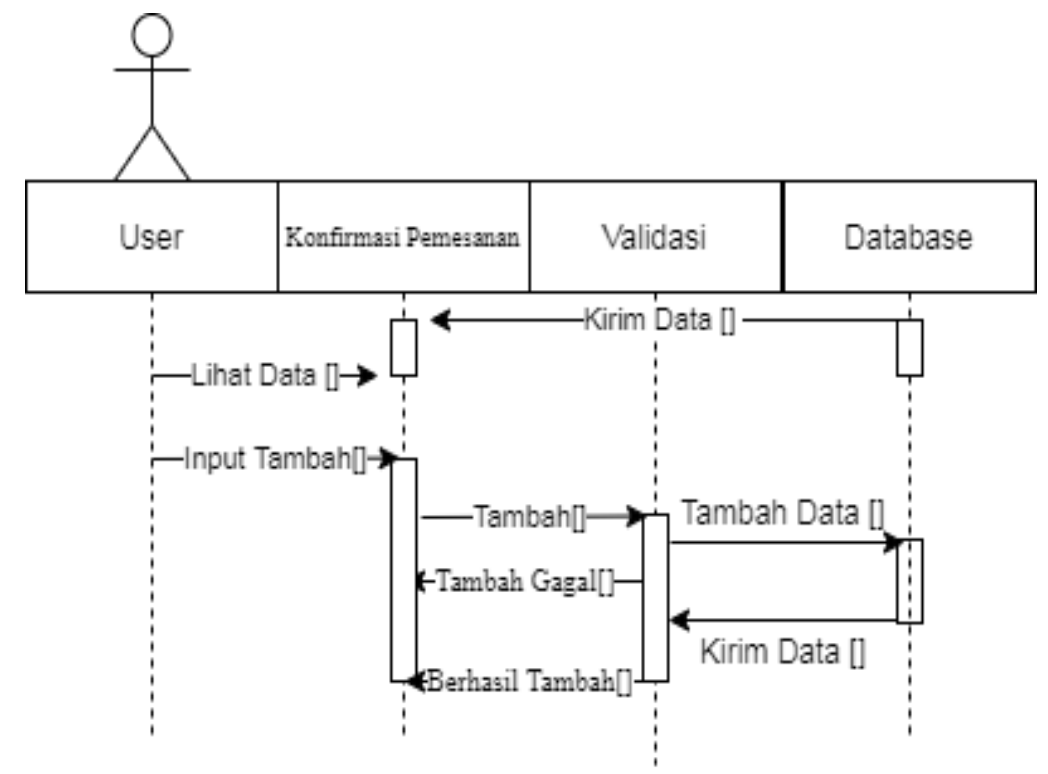

Sumber: Hasil Penelitian (2021)

Gambar 9. Sequence Diagram Halaman Konfirmasi Pemesanan

Gambar 10 menunjukkan sequence diagram pada tahap halaman admin melakukan order detail.

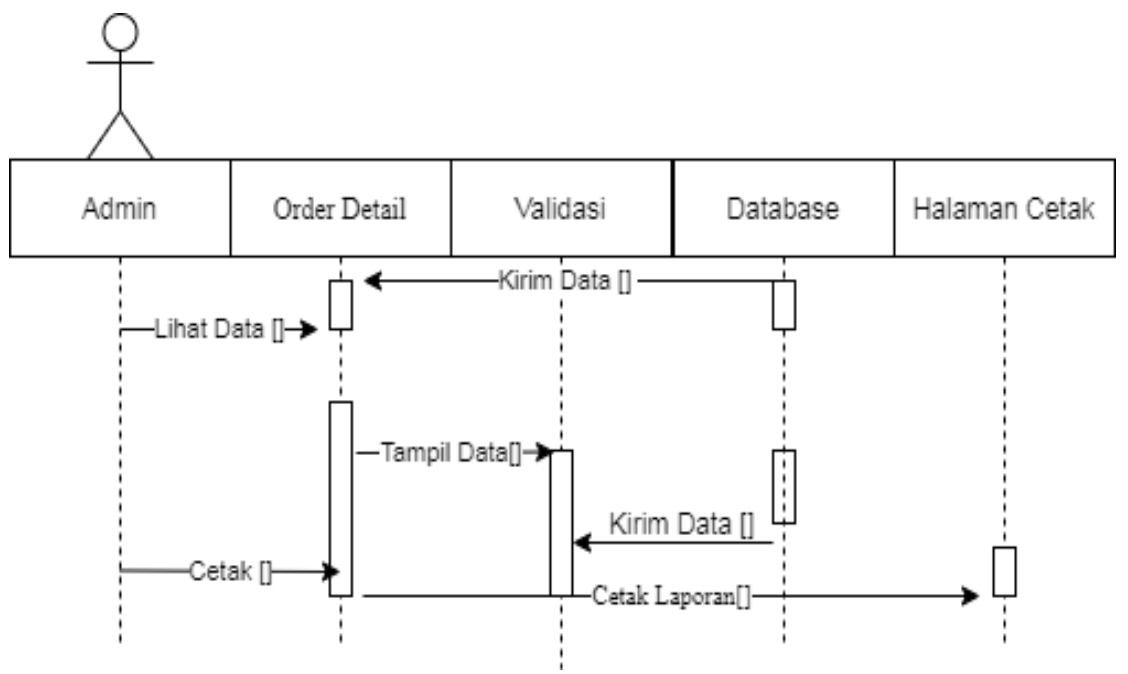

Sumber: Hasil Penelitian (2021)

Gambar 10. Sequence Diagram Halaman Admin Order Detail

\section{Kesimpulan}

Berdasarkan hasil observasi yang penulis lakukan pada Queen Shoes Cleaning serta pembahasan yang dilakukan oleh penulis, maka dapat diambil kesimpulan sebagai berikut: Perancangan sistem informasi laundry sepatu berbasis web ini dapat membantu pihak Queen Shoes Cleaning dalam melakukan transaksi, Pendataan dan arsip yang rapih menggunakan website tersbut, Memberikan kemudahan bagi pelanggan yang ingin mencuci sepatu tanpa 
harus datang langsung ke toko. Diharapkan kedepannya untuk Queen Shoes Cleaning yaitu: Pada Queen Shoes Cleaning sistem yang masih bersifat manual, sebaiknya menggunakan sistem informasi berbasis web, sehingga dapat mempercepat proses Transaksi, Pada sistem informasi berbasis web dapat meningkatkan kinerja karyawan bagian admin untuk dapat mengelola pemesanan yang masuk dan pencatatan laporan yang baru secara efektif dan efisien, Diharapkan sistem informasi ini dapat dikembangkan sehingga dapat melayani konsumen secara online.

\section{Daftar Pustaka}

Hudaya, H. A., \& Suryana, T. (2018). Pembangunan Aplikasi Deteksi Tingkat Kekotoran Dan Rekomendasi Jenis Treatment Pada Laundry Sepatu. 1.

Khasanah, F. N., Informatika, T., Testing, B., Testing, B. B., \& Based, L. (2018). Pengujian Fungsional Dan Non Fungsional Aplikasi Informasi Telepon Darurat Berbasis Android. Information System For Educators And Professionals, 3(1), 79-90.

Khasanah, F. N., Rofiah, S., \& Setiyadi, D. (2019). Metode User Centered Design Dalam Merancang Tampilan Antarmuka Ecommerce Penjualan Pupuk Berbasis Website Menggunakan Aplikasi Balsamiq Mockups. JAST: Jurnal Aplikasi Sains Dan Teknologi, 3(2), 14. https://doi.org/10.33366/jast.v3i2.1443

M.Shalahuddin, R. A. . dan. (2016). rekayasa perangkat lunak (ketiga). informatika bandung.

Merdeka. (2021). Belanja Online Meningkat saat Pandemi, Ini Daftar E-Commerce Paling Banyak Dikunjungi.

Nugroho, B. (2013). Dasar Pemrograman Web PHP-mySQL Dengan Dreamweaver.

Pressmann, R. . (2015). Softeware Engineering A Practitioner's Approach Seventh Edition.

Raksipratama, D., \& Iqbal Firdaus, M. (2020). Sistem Informasi Pelayanan Jasa Cuci Sepatu Di Shine Shoes Banjarmasin Dengan Sms Gateway. 1(1), 1.

Soekamto, R. A., \& Shalahuddin, M. (2018). Rekayasa Perangkat Lunak (p. 29).

Sofian, S. (2017). Penerapan Sistem Informasi E-Commerce Berbasis Web (Studi Kasus Untuk Vendor Pernikahan ). 6(2), 52-57.

Widodo, A. W., \& Kurnianingtyas, D. (2017). Sistem Basis Data.

Yulisar, A. A. (2019). Sistem Informasi Pelayanan Jasa Laundry Sepatu Pada Shoes Cleaning Majalengka. 1. 